\title{
AN UNCONSTRUCTABLE INDIAN OCEAN: AMITAV GHOSH'S ECOLOGICAL IMAGINARY IN SEA OF POPPIES AND THE GREAT DERANGEMENT
}

\author{
Maria-Sabina Draga Alexandru \\ University of Bucharest (Romania)
}

\section{Abstract}

In his 2019 book The Unconstructable Earth: An Ecology of Separation, Frédéric Neyrat opposes the idea that, having come very close to destroying the Earth in the Anthropocene, man can now use geoengineering to reconstruct it. Instead, Neyrat proposes an "ecology of separation" which recognizes the Earth's self-regenerating capacity as essentially separate from man's intrusion, thus suggesting that the condition for the world to survive in an age of increasing apocalyptic dangers is an acceptance of the limitations of human agency. This article will argue that Amitav Ghosh's own ecological project, developed in his 2016 essaybook The Great Derangement: Climate Change and the Unthinkable, which started as early as his historical opium war novel Sea of Poppies (2008), narrates an ecology of separation similar to Neyrat's, a version of Graham Huggan and Helen Tiffin's "green postcolonialism" that confronts Eurocentric aggression against non-European civilizations and against nature.

Keywords: Ecological Imaginary, Ecology of Separation, Green Postcolonialism, Indian Ocean, Unconstructable.

\section{UN OCÉANO ÍNDICO INCONSTRUIBLE: EL IMAGINARIO ECOLÓGICO DE AMITAV GHOSH EN SEA OF POPPIES Y THE GREAT DERANGEMENT}

\section{RESUMEN}

En su libro The Unconstructable Earth: An Ecology of Separation (2019), Frédéric Neyrat se opone a la idea de que, habiendo estado muy cerca de destruir la Tierra en el Antropoceno, el hombre trata de usar la geoingeniería para reconstruirla. En cambio, Neyrat propone una «ecología de la separación» que reconoce la capacidad de la Tierra de autorregenerarse sin la intrusión del hombre, lo que sugiere que la condición para que el mundo sobreviva en una era de crecientes peligros apocalípticos es la aceptación de las limitaciones de los seres humanos. Este artículo argumenta que el propio proyecto ecológico de Amitav Ghosh, desarrollado en su libro de ensayos The Great Derangement: Climate Change and the Unthinkable (2016), que había ya empezado en su novela histórica sobre la guerra del opio, Sea of Poppies (2008), narra una ecología de separación similar a la de Neyrat, una versión del "poscolonialismo verde” de Graham Huggan y Helen Tiffin que enfrenta la agresión eurocéntrica contra las civilizaciones no europeas y contra la naturaleza.

Palabras clave: imaginario ecológico, ecología de la separación, Poscolonialismo Verde, Océano Índico, inconstruible. 
In his 2019 book The Unconstructable Earth: An Ecology of Separation, Frédéric Neyrat discusses the discovery of the new planet Earth, which, having practically been destroyed by man in the Anthropocene, has in recent times been subjected to a painful process of eco-constructivist climate geoengineering, meant to repair what had previously been damaged (1-9). Neyrat takes issue with the idea that any such reconstruction may be possible and argues that the only way to save the planet is a cancellation of the uninspired nature-culture encounter in favour of a total separation between technology and nature. Having come very close to destroying the Earth in the Anthropocene, man has been trying to use geoengineering to reconstruct it. Yet, the extent to which science can be used to fix the damage is placed under a big question mark in the book. Instead, Neyrat promotes an "ecology of separation" which, as its name suggests, recognizes the Earth's self-regenerating capacity as essentially separate from man's intrusion, thus suggesting that the condition for the world to survive in an age of increasing apocalyptic danger is a necessary acceptance of the limitations of human agency and the need to respect the sovereignty of nature. Neyrat pleads for an "unconstructable Earth", which, to be saved, needs not a new kind of nature-friendly human intervention, but, on the contrary, to be left alone, to be allowed to follow its own rhythms rather than externally imposed human or technological ones. The planet seems to protect itself from the damaging human agency of the late capitalist age through withdrawing in a kind of subjective subconscious of its own, which calls for freedom from human intervention:

In order to make the Earth opaque enough to resist the technological dominance of the hypermoderns, we must emphasize its unconstructable part, which is not in opposition to its living part but precedes it, supports it, and can be aligned with it. This nocturnal, unobjective, and asubjective part is that which withdraws from human dominance and is subsequently established as the unattainable condition of humanity. (Neyrat 168)

Neyrat's concept of unconstructability serves to promote what, in the title of his book, he calls an "ecology of separation". This separation principle consists of maintaining the human factor and the planet's natural environment as distinctly apart as possible, on the basis of a declared respect for the natural and to the detriment of a long-established principle of universal human superiority over everything there is. Nature, instead, is treated as an entity in its own right, which has a balance of its own that is best left untroubled and which deserves suitable respect.

Neyrat's book proposes a version of ecology -an "ecology of separation"different from the one that has by now become classical, promoted, among others, by Donna Haraway. Her book The Companion Species Manifesto (2003) describes a dynamic intertwining of the natural with the culturally constructed or the man-made, of the body with the mind, of the rational with the emotional, of the masculine with the feminine etc. Thus, Haraway's solution to the human destruction of the environment is one of intertwining and even "friendship" between humans and the environment, a continuum between the human and the natural conceptualized 
as "Natureculture". Neyrat opposes such a continuum, on accounts of the fact that the natural and the human (often understood as the technological) are very different and experience has shown that too much interaction between them leads to their damaging each other. Neyrat's dissent from the common view is just one example of the diversity of perspectives that have pervaded environmental humanities, a field of enquiry increasingly visible on the global stage.

In recent times, the rise of environmental humanities has often met with the similarly spectacular trajectory of global writing in English. In a postcolonial light, this confirms an evolution in world pluralism and a general increase in respect for fellow human beings, as well as for the planet. Along cognate lines, Huggan and Tiffin's green postcolonialism (Interventions, 2007) marks an important development in postcolonial ecocriticism. It is mostly an opportunity to examine relationships between humans, animals and nature in postcolonial literary texts in order to show that

human liberation will never be fully achieved without challenging the ways human societies have constructed themselves in hierarchical relation to other human and non-human communities, and without imagining new ways in which these ecologically connected groupings can be creatively transformed. (Huggan \& Tiffin 2010: ii)

This involves a reconsideration of the ways in which we position ourselves with respect to animals and the environment and how nature interferes with our actions and decisions. It also has an impact on the bigger chapter of postcolonial history rewriting, which calls for an act of reassessment from the perspective of the former colonised and not of the colonisers. In his 2009 article "The Climate of History", Dipesh Chakrabarty argues, from the same perspective of the formerly marginalized, for a more accurate, cleaner version of history, rewritten so as to give a voice to the formerly voiceless instead of the previous narrative of imperial power chronicled in traditional history books. This rejection of history written from the West and from the centre, in good New Historicist tradition, but expanded so as to include non-human histories too, in a symbiosis with the actually very related human history, shows that ecology should not only be about the natural environment, but also about the environment of inter-human relations. Thinking in a cleaner, saner way and repairing exclusions is a principle that should dominate the whole way in which, as humans, we position ourselves with respect to the world, and this includes our whole range of connections. So, Chakrabarty's project is one that aims at deconstructing anthropocentrism in the world and its mirror image in colonial history, Eurocentrism. This comes close to Dominic Head's "deep ecology" and epitomizes a radical shift in our thinking about the world, as Huggan and Tiffin go on to show:

The British ecocritic Dominic Head has prioritized the 'fundamental social restructuring associated with deep ecology' over the 'provisional management strateg[ies]' of environmentalism (1999: 27). For Head, as for his American counterpart Lawrence Buell, environmental crises and Western thought are 
intrinsically interwoven: 'Western metaphysics and ethics need revision before we can address today's environmental problems' (Buell 1995: 2). We need, argues Buell, 'better ways of imagining nature and humanity's relation to it' (ibid.). The crisis in Western thinking that Buell, among several others, has identified is intimately connected to Europe's history of conquest and colonization and the ideological hegemony it (re)produced. (Huggan and Tiffin 2007: 5)

This crisis of nature seems to provide a mirror of human crises, which can be of many kinds, yet seem to ultimately reflect on the extent of the damage they produce to our environment. Thus, since nature is the ultimate measure of all events of consequence on Earth, and since postcolonialism as a discipline has long become an official (rather than subversive) discourse taught in universities, it follows that the current fact of increasingly redefining postcolonialism as green postcolonialism is a legitimate one.

Green postcolonialism, however, is not just critical; it is also celebratory. Both postcolonialism and ecocriticism are, at least in part, utopian discourses aimed at providing conceptual possibilities for a material transformation of the world. (Huggan and Tiffin 2007: 10)

As there has been an increasingly stronger connection between the environment and global writing in English, even more so in the current global Covid-19 crisis, more and more areas of the humanities focus around environmental concerns. Thus, as we speak, an area of intersection is being created between fields of the humanities such as history, philosophy, literature, music, cultural studies (with its ramifications) and the more and more visible ecological concerns that have emerged in the contemporary world. All of this seems to be of particular interest in recent global writing in English, which exists in a transnational space that has been all the more affected by the Covid-19 crisis.

Ecocriticism as a broadly emerging critical perspective views literature as "an ecological principle or an ecological energy within the larger system of cultural discourses" (Zapf 55), a form of cultural ecology that has "moved beyond former one-sided, biological-deterministic views of the nature-culture relationship towards the recognition of the difference and relatively independent dynamics of cultural and intellectual phenomena" (Zapf 51). Eco-fiction is imaginative literature (i.e., fictional or non-fictional literature which uses the powers of imagination to discuss and even criticize aspects of real life, while pretending to be purely fictional) understood as a form of cultural ecology, whose function is both critical and activist. It provides means to discuss important political issues more freely and openly than politics can, through the power of example, but also through the capacity of literature to imagine alternative worlds, in which the wrongs of society are challenged and sometimes even put right in the possible world constructed in the book.

One author who has illustrated and elaborated on such concerns in an almost systematic manner, in both his fiction and his non-fiction, is Amitav Ghosh. His fiction writing is generally pervaded by an ecological perspective on the world, not only at the level of content, but also in his narrative structures and technique 
and character building. Ghosh's work promotes a radical rethinking of human interactions in an ecological light, which, I would like to argue, imagines the Indian Ocean as a kind of receptacle of dynamic forces in which older and newer perspectives and attitudes melt and interact. This article uses Neyrat's theory as a lens through which to read Amitav Ghosh's own ecological project in his 2017 essay-book The Great Derangement: Climate Change and the Unthinkable, read in conjunction with his historical opium war novel Sea of Poppies (2008). In the light of the current coronavirus crisis, Ghosh's own version of what Graham Huggan and Helen Tiffin call a "green postcolonialism" (a technology-proof version of an emancipatory move of the margin against an oppressive, polluting centre) shares a deep concern with the ways in which the relationship between nature and culture, which has changed dramatically in the recent decades, mirrors a changing in the relationship between the "West" and the "East" and an increased fluidity in world hierarchies, as suggested by the triad "Land-River-Sea" proposed by the three parts of the Ibis Trilogy. A similar interconnectedness of how the world is made is suggested by the similar three-part structure of The Great Derangement ("StoriesHistory-Politics"), which confirms the traditional Hindu chain of being, in terms of which everything is connected. If colonialism took European superiority over non-European civilizations for granted, it is now alternative, non-European forms of knowledge that prevail over western knowledge when it comes to facing nature's revolt against various kinds of prolonged human aggression.

Ghosh's Indian Ocean becomes a kind of imaginary world outside history, which challenges not only many received conceptions of former times (given that some of his writing, for example, looks back upon history), but also some conceptions still shared by the world we live in. I will base my discussion on Ghosh's 2008 Sea of Poppies, the first of his historical Ibis trilogy about the opium wars, which is based on such views, later to be continued in Ghosh's fiction. While the trilogy relies on a project that Ghosh announces since The Shadow Lines, which is one of relativising history and its limitations, Sea of Poppies, through its tripartite structure (Land, River and Sea) spells out a whole process of evolution from traditional, immutable mentalities, through to a path towards evolution and on to the spatial and symbolical fluidity granted by the Indian Ocean.

As already mentioned, Ghosh has been practicing a fiction of fluid borders at least since 1988, when he published his classic on the topic, The Shadow Lines. A year earlier, the same fluid physical lines separating states, which reflects on how identity is conceptualized in the respective territories, had been stated by Gloria Anzaldúa in her Borderlands/ La frontera. The latter's translation ambiguity is afforded by the book's bilingualism: "frontera" means "border" rather than "borderland", so the passage to English complicates the concept, adding a meaningful zone of transition to it. This, like Ghosh's lines, which are not real, but shadowy, extends to many formerly strict categories associated with borders, such as ethnic or national identity, caste, gender, religion and so forth. This is visible in the construction of Ghosh's characters, as Robert Dixon notices: "The characters in Ghosh's novels do not occupy discrete cultures, but 'dwell in travel' in cultural spaces that flow across borders - the 'shadow lines' drawn around modern nation states"... [They 
inhabit] "a discursive space that flows across political and national boundaries, and even across generations in time" (Dixon 10; 18). As, in the contemporary world, separate, discrete cultures have given way to categories of fluidity and change as migration/ relocation has become increasingly frequent, Ghosh's interest in the dynamic of cultures and in cross-border movements, in the always changing nature of identity rather than rigid categories responsible for dividing people, has not only continued in his novels (primarily the Ibis trilogy, The Hungry Tide and Gun Island), but was also taken to a more theoretical level in his 2016 essay book The Great Derangement. Thus, I propose a reading of The Great Derangement as an essay book on climate change in conjunction with Sea of Poppies (in particular Part III: Sea, whose title refers both to the Indian Ocean and to the sea of poppies of the novel's title), since this novel is not only the first in the Ibis trilogy, but among the first of Ghosh's novels that focus on the impact of the environment on human destinies since former times.

Sea of Poppies is built around the initially parallel destinies of many characters, each of them with their own stories of displacement, who come together by chance and end up forming alliances that transcend social categories, time and the original spatial distances that divided them. This act of coming together happens mostly in Part III, when they meet on the Ibis, the schooner that takes them all to the opium plantations in Mauritius, whether as indentured labourers or to different ends. The transformative effect that the Ibis journey has on them is a reversal of the traditional kala pani, the act of crossing the black waters and thus cutting off all bridges from home, including losing caste. The moment of departure, when the actual crossing is about to begin, is marked in Part III: Sea of the novel as a particularly meaningful experience, stronger than any other, for those who take part in it:

Slowly, as the vessel's motion made itself felt in the pit of every stomach, the noise yielded to a pregnant, fearful stillness. Now the migrants began to absorb the finality of what was under way: yes, they were moving, they were afloat, heading towards the void of the Black Water; neither death nor birth was as fearsome a passage as this, neither being experienced in full consciousness. Slowly, the rioters backed away from the ladder and returned to their mats. Somewhere in the darkness, a voice, trembling in awe, uttered the first syllables of the Gayatri Mantra - and Neel, who had been made to learn the words almost as soon as he could speak, now found himself saying them, as if for the first time: Om, bhur bhuvah swah, tat savitur varenyam... O giver of life, remover of pain and sorrow... (Ghosh 2008: 387-388)

Difficult as this crossing might be, though, it is the most important scene in the novel and, ultimately, a symbolical marker of progress from bondage to freedom (even though that freedom may include other forms of bondage), from one particular historical stage to another. It also involves, as seen from the perspective of the whole of Ghosh's work, a radical challenging of the inviolability of strict social categories such as caste. For Deeti, the widow whom her secret untouchable admirer Kalua saves from her dead husband's funeral pyre, losing caste through both crossing the black waters and marrying Kalua is not at all the tragedy it would normally be in the Hindu background. It is, on the contrary, a life-giving path to freedom and 
to a new, better life, despite losing caste. This is a transformation all the people on board the Ibis experience as they embark, actually, on a new historical stage in the development of societies around the Indian Ocean, which becomes a world in itself, a fluid host of change and movement towards another and, in some ways, better world.

Ghosh's later essay book on climate change, The Great Derangement, also consists of three parts, which are announced from the very beginning to be intrinsic to the logic of the book, to such an extent that they are even arranged in a visually attractive triangular shape in the table of contents: Part I-Stories, Part II - History and Part III - Politics. In the first part, entitled Stories, Ghosh builds a whole theory around how stories come into shape, as human civilization interacts with the rhythms of nature, sometimes to the detriment of one or the other. Ghosh notices that there is not enough literature on climate change and, while his own writing seems to aim at providing a solution to the problem, he also comes close to laying the foundations of an ecocritical literary theory. This theory is based on the interconnections between stories and the world from which they emerge and with which they continually communicate. In Indian tradition, a story grows from another "like a lotus vine", to quote from another contemporary Indian practitioner of storytelling in novel form, Vikram Chandra (Chandra 1995: 617). At the end of Chandra's novel Red Earth and Pouring Rain the most important thing when a person dies is for their story to survive. Chandra is fascinated by the never-ending interaction between stories and the reality they grow from (which he explores in most of his work), as he confesses in an interview:

I think for me it's really illuminating to see how people use stories. And what I mean by that is that a story I tell today is similar, but not necessarily the same thing that my grandfather was telling, you know. Here is this narrative coming back to me through somebody else's interpretation. I guess it's narcissistic in some sense, but it's very engaging. The monkey in Red Earth realises that he's telling his story, but it changes as it goes on and then you'll have to let it go. I think it's a great pleasure to me in hearing what people have to say. Sometimes it's strange, because story connects back to history. I got letters from several descendants of James Skinner. And that was amazing because, you know, people who were part of the story that I was telling wrote to me, that's pretty moving. (Chandra 13)

Chandra discusses here the historical inspiration he got for his 1995 novel Red Earth and Pouring Rain. Having been built on significant nineteenth-century detail which he turned into story, historical detail then returns to him in the guise of descendants of one of his characters, who write letters to him and comment on the making of the novel. The idea of people using stories to fill in gaps in history or to answer questions about life that are difficult to answer otherwise brings into the picture an idea of narrative knowledge which reigns supreme among all other knowledges humanity has access to. Since the Mahabharata, the foundation epic which is considered by Indians to contain everything there is and has ever been in the world (itihasa), stories have been regarded as an important (if not the main) source of knowledge. Contemporary Indian authors are rediscovering this asset and reinstating the revigorating power of storytelling in a global world in ecological 
crisis, where a perspective on the world that dwells in process rather than stasis is needed more than at any other point in time.

Like Vikram Chandra, Amitav Ghosh is one passionate storyteller, who, moreover, takes storytelling, from the Buddhist Jataka stories and Urdu dastaans (Ghosh 2016: 18) to narrative forms such as the novel nowadays, beyond the already featured human and superhuman world, into the universe of nature and environmental concerns. Thus, to return to The Great Derangement, the book's three parts create a system that practically imagines the whole fabric of the world through the lens of storytelling. Just as people are never ready for the spectacular turns of the plot in a well-written thriller, nor are they ready for natural disasters (Ghosh 2016: 25), of which he chooses a few whose stories he tells with lavish details. Some of these are famous cases, such as that of hurricane Sandy that ravaged New York in 2012, others are lived experiences, such as the tornado that hit north Delhi on March 17, 1978, which Ghosh witnessed directly, having accidentally taken a different turn on his way home from work on that day. He agrees with the fact that the main reason for such phenomena is the current global warming. However, he integrates them in a wider historical perspective at the beginning of The Great Derangement, as he tells the story of his ancestors:

My ancestors were ecological refugees long before the term was invented.

They were from what is now Bangladesh, and their village was on the shore of the Padma River, one of the mightiest waterways in the land. The story, as my father told it, was this: one day in the mid-1850s the great river suddenly changed course, drowning the village; only a few of the inhabitants had managed to escape to higher ground. It was this catastrophe that had unmoored our forebears; in its wake they began to move westward and did not stop until the year 1856, when they settled once again on the banks of a river, the Ganges, in Bihar. (Ghosh 2016: 3-4)

By mentioning natural catastrophes as a reason that has always displaced populations, Ghosh shows that the current climate change situation is one episode in the epic of nature in interaction with human settlements. The interaction of the human factor with water ("living by the water", Ghosh 2016: 37) seems to be of particular concern. However, it seems that such concern is caused primarily by interactions between land and water (as we see in Sea of Poppies in Part II: River, where the Ganges provides a path of freedom towards the sea, but then the true freedom is granted by the Indian Ocean).

That nature has its own epic is an idea supported by the concept of an "environmental uncanny" for which the author makes a case (Ghosh 2016: 32), to be found, for example, in the mystery of tiger stories in the Sundarbans (Ghosh 2016: 30). Discussing nature in such terms derived from literary criticism provides a methodology of analysis that we could further apply in a reading of Ghosh's own fiction. Thus, we recognize in the narrative structure of Sea of Poppies the complex interaction between stories, history and politics discussed in The Great Derangement, yet in the former case adapted to the novel's historical narrative context. Irrespective of their situatedness in time and history, Ghosh's characters are 
generally modern-minded, mobile characters in perpetual movement and change, with an understanding of human relationships and values that goes far beyond contextual conditionings. History, approached like just another story, is tackled from the perspective of the same continuity across everything that exists and has ever existed. Thus, for instance, the author identifies a blatant connection between imperialism and climate change, to be found in the way in which European imperial powers treated Asian economies along centuries (Ghosh 2016: 87). Ghosh's approach to history is in agreement with Dipesh Chakrabarty in "The Climate of History", which he discusses in The Great Derangement as one particular way to read the interconnections between stories that focus on humans (of which history is one) and those very similar ones that focus on nature (Ghosh 2016: 9-25). In his fictional and non-fictional writing, Ghosh practices a dynamic model of history, aiming in the Ibis trilogy at its rereading from the margins rather than from the centre, in the line of Subaltern Studies and New Historicism.

The universe on board the Ibis comes close to Donna Haraway's natureculture continuum, with those characters who insist on rigid social divisions being eliminated (Bhyro Singh is killed by Kalua, whom he despises because he is an untouchable and whose wife he offends) and with interhuman connections being formed across all social, geographical and cultural borders (Deeti and Kalua, Paulette and Zachary or Neel and Ah Fatt). The world on board the Ibis resembles a kind of utopian, imaginary universe in which all that has life is equal, which leads to the erasure of strict categories such as the inviolability of marriage or the incompatibility of castes. This world has a flexibility that creates a continuum between humans of different castes, genders and social categories, just as in Haraway's theory a continuum is created between life and the mind, the animal, the human and the man-made (or the machine). The Ganges -the sacred river which here makes the transition from land, the space of rigid, rooted rules, to the fluid, dynamic sea of change which is the Indian Ocean - is associated with a complex plethora of rituals of death, rebirth and purification, as Hindu ritual borrows from the symbolism of nature. Such a scene, which prepares the mental fluidity that accompanies the journey down the Ganges, is the moment of true ecological intimacy represented in Sea of Poppies by Deeti and Kalua's wedding in nature:

Although she had no more of a plan than he did, she said: We'll go away, far away, we'll find a place where no one will know anything about us except that we are married.

Married? he said.

Yes.

Squirming out of his arms, she wrapped herself loosely in her sari and went off towards the river. Where are you going? he shouted after her. You'll see, she called over her shoulder. And when she came back, with her sari draped over her body like a veil of gossamer, it was with an armload of wild-flowers, blooming on the bank. Plucking a few long hairs from her head, she strung the flowers together to make two garlands: one she gave to him, and the other she took herself, lifting it up above his head and slipping it around his neck. Now he too knew what to do and when the exchange of garlands had bound them together, they sat for a while, 
awed by the enormity of what they had done. Then she crept into his arms again and was swept into the embracing warmth of his body, as wide and sheltering as the dark earth. (Ghosh 2008: 188-189)

This scene of love that defies all limitations, even death (previous to this, Kalua had just saved Deeti from sati) is a symbolical trigger of action in Sea of Poppies, unleashing creative energies for building a new life which would have been impossible in the absence of such a will to break down rigid social rules. This seems to be the starting point of Ghosh's ecological thinking, a form of perceiving the world as free from preconceived ideas as possible, as ready as possible to experience the dynamic of the human world and of nature directly, unmediated by any lens.

In The Great Derangement, Ghosh seems to have gone one step further than Sea of Poppies, beyond a celebration of the possible harmony between nature and human beings (as in the scene above) towards a recognition of the fact that there are moments in nature (such as hurricanes) which escape human control altogether and which, at least in the first instance, do not benefit humans. In a recent review of Ghosh's latest novel, Gun Island, published in The Guardian, Alex Clark calls The Great Derangement "an examination of collective denial in the face of climate breakdown" (Clark 2019). This collective denial, which has been going on for a long time, has mostly consisted in unlimited human intervention in the balance of nature. While, like Sea of Poppies, The Great Derangement still celebrates the harmony between human beings and the environment, the third part of the latter, entitled Politics, makes a case for the fact that a change in the politics of human behaviour towards nature has to change for the current climate crisis to be overcome or at least stopped. The benefits of human intervention in nature are exposed as being an illusion, as the book concludes by pleading for action in a way that, interpreted in the light of Ghosh's whole work, seems to lead towards an ecology of separation:

The struggle for action will no doubt be difficult and hard-fought, and no matter what it achieves, it is already too late to avoid some serious disruptions of the global climate. But I would like to believe that out of this struggle will be born a generation that will be able to look upon the world with clearer eyes than those that preceded it; that they will be able to transcend the isolation in which humanity was entrapped in the time of its derangement; that they will rediscover their kinship with other beings, and that this vision, at once new and ancient, will find expression in a transformed and renewed art and literature. (Ghosh 2016: 161-162)

The isolation mentioned here very likely refers to the conflictual relationship created between humankind and the environment at a time of increased number of natural catastrophes such as tornadoes and hurricanes. However, it would be hard for today's reader not to connect it to the many periods of isolation of varying intensity at the time of the Covid-19 global crisis. Whether this crisis, whose extremity has surpassed that of many other crises, is due to human negligence towards the environment is not yet altogether clear. As for Ghosh, even though he continues to celebrate an always desirable harmony between humans and nature, such harmony, as suggested by the above reference to a new generation that should learn to look 
upon nature with clearer eyes, will only be possible in conjunction with a practice of respect towards and non-intervention in nature, a kind of ecology of separation as described by Neyrat. Somewhat paradoxically, harmony with nature seems to require a separation from it. This, however, implies not a renewed nature-culture division, but a nature-culture continuum based on respect for each other's specific ways of being.

Reviews sent to author: $22 / 12 / 2020$

Revised paper accepted for publication: 02/02/2021 


\section{WORKS CITED}

Chandra, Vikram. Red Earth and Pouring Rain. Faber, 1995.

Chandra, Vikram. "Virtual Reality on Infinite Bandwidth": Vikram Chandra interviewed by MariaSabina Alexandru, JCL. 40/5 (2005): 5-21.

Clark, Alex. "Gun Island by Amitav Ghosh Review -Climate and Culture in Crisis." The Guardian, 5 June, 2019, https://www.theguardian.com/books/2019/jun/05/gun-island-amitav-ghoshreview. Accessed 15 December 2020.

Dixon, Robert. "Travelling in the West': The Writing of Amitav Ghosh.” Amitav Ghosh: A Critical Companion. Ed. Tabish Khair, Permanent Black, 2003. 9-35.

Grosh, Amitav. Sea of Poppies. John Murray, 2008.

Grosh, Amitav. The Great Derangement. The U of Chicago Press, 2016.

Haraway, Donna. The Companion Species Manifesto: Dogs, People, and Significant Otherness. Prickly Paradigm Press, 2003.

Huggan, Graham and Helen Tiffin. Postcolonial Ecocriticism: Literature, Animals, Environment. Routledge, 2010.

Huggan, Graham and Helen Tiffin. “Green Postcolonialism.” Interventions 9/1 (2007): 1-11. Doi: https://doi.org/10.1080/13698010601173783. Accessed 15 Nov. 2020.

Neyrat, Frédéric. The Unconstructable Earth: An Ecology of Separation, Fordham UP, 2019.

ZAPF, Hubert. "The State of Ecocriticism and the Function of Literature as Cultural Ecology." Nature in Literary and Cultural Studies. Transatlantic Conversations on Ecocriticism. Eds. Catrin Gersdorf and Sylvia Mayer. Rodopi, 2006. 49-69. 